\title{
Resistance in Eastern European Pyrus Germplasm to Pear Psylla Nymphal Feeding
}

\author{
R.L. Bell ${ }^{1}$ and L.C. Stuart ${ }^{2}$ \\ Appalachian Fruit Research Station, U.S. Department of Agriculture, \\ Agricultural Research Service, 45 Wiltshire Road, Kearneysville, \\ WV 25430-9802
}

Additional index words. Insects, Homoptera, Cacopsylla pyricola, Psylla, antibiosis, antixenosis, plant genetic resources

\begin{abstract}
Fifty-nine cultivars and wild seedlings of pear (Pyrus spp.) from Eastern Europe were evaluated for resistance to feeding by early instar pear psylla [Cacopsylla pyricola (Foerster)] in a 24-hour assay. 'Bartlett' ( $P$. communis L.) and NY 10352 ( $P$. communis $\times P$. ussuriensis Maxim. $\mathbf{B C}_{1}$ hybrid) were used as susceptible and resistant controls, respectively. A. high degree of resistance, measured as increased mortality and reduced frequency of feeding, was found in 11 plant introductions: 'Erabasma' (PI 483370), 'Krupan Burnusus' (PI 483387), 'Topka' (PI 484489), 'Zelinka' (PI 483393), 'Mednik' (PI 483399), 'Karamanlika' (PI 502165), 'Katman' (PI 502172), 'Smokvarka' (PI 502176), 'Obican Vodenac' (PI 502177), a clone thought to be 'Smiljerka' (PI 502178), and an unnamed seedling (PI 506382).
\end{abstract}

The pear psylla is one of the most serious arthropod pests of pear in North America and Europe. All of the cultivars of the European dessert pear ( $P$. communis L.) grown commercially are susceptible. Currently, biological controls are of limited effectiveness (Westigard and Zwick, 1979), and resistance to insecticides has developed rapidly (Croft et al., 1989). Host plant resistance would therefore be a valuable control strategy, significantly reducing production costs. Resistance to the pear psylla has been demonstrated in East Asian pear species, $P$. betulifolia Bunge, $P$. calleryana Decne., $P$. faunei Schneid., $P$. ussuriensis Maxim., and $P$. $\times$ bretschneideri Rehd. (Quamme, 1984; Westigard et al., 1970), and in P. ussuriensis $\times$ P. communis hybrids (Harris, 1973; Harris and Lamb, 1973; Quamme, 1984). Small fruit size or gritty or coarse texture limits the usefulness of some of this germplasm for rapid incorporation of their high levels of resistance into new cultivars with European-type fruit quality. Resistance has been reported for a few genotypes of $P$. $n i$ valis Jacq., the "snow pear" (Westigard et al., 1970), and in 'Pitoma Slanopadja', presumably a $P$. communis $\times P$. amydaliformis hybrid (Stancevic et al., 1984). Moderately high host plant resistance within $P$. communis has been reported only for 'Spina Carpi' (Quarta and Puggioni, 1985; Briolini et al., 1988), a cultivar of poor fruit quality.

All of the high-quality cultivars of $P$.

Received for publication 20 Sept. 1989. We acknowledge [he support of B.A. Butt and the technical assistance of Wayne Zook and Suzanne Lucas. The cost of publishing this paper was defrayed in part by the payment of page charges. Under postal regulations, this paper therefore must be hereby marked advertisement solely to indicate this fact. 'Research Horticulturist.

${ }^{2}$ Biological Laboratory Technician. northern areas of Europe, C. pyrisuga
North America, C. pyri (L.) and, in the more as a class with the next highest whole number.
Table 1. Analysis of variance of pear psylla nymphal feeding.

\begin{tabular}{clrrc}
\hline \hline $\begin{array}{c}\text { Data } \\
\text { set }\end{array}$ & Source & df & $\begin{array}{r}\text { Mean } \\
\text { square }\end{array}$ & $\begin{array}{c}\text { Probability } \\
>\mathrm{F}\end{array}$ \\
\hline 1 & Trial & 4 & 8.1 & 0.2223 \\
& Genotype & 39 & 145.9 & 0.0001 \\
& Error & 156 & 5.6 & \\
2 & Trial & 4 & 18.1 & 0.1465 \\
& Genotype & 22 & 117.8 & 0.0001 \\
& Error & 88 & 10.3 & \\
\hline
\end{tabular}

(Foerster) are endemic in the collection areas. It was assumed that the host-related biology of these closely related pear psyllids would be similar.

The principle modes of resistance are antixenosis, observed in the insect as ovipositional nonpreference, and antibiosis, which results in nymphal mortality-and delayed development (Westigard et al., 1970; Harris, 1973; Harris and Lamb, 1973). Feeding inhibition or reduced feeding frequency leads directly to nymphal mortality and delayed development (Butt et al., 1989). A rapid nymphal feeding bioassay has been developed to screen pear germplasm for antibiosis-based resistance (Butt et al., 1988).

This study was undertaken to evaluate pear germplasm introduced from Eastern Europe for resistance to pear psylla nymphal feeding. Sources of resistance within this gene pool might be, used more effectively in a breeding program than sources from East Asian species because of the similarity in fruit characteristics within $P$. communis.

Germplasm, bioassay, and experimental design. The germplasm examined consisted of 59 accessions of pear from Eastern Europe released from plant quarantine since 1978. Brief descriptions have been published (van der Zwet et al., 1987, 1989). The bioassay procedure was modified from techniques described previously (Butt et al., 1988). First or second instar pear psylla nymphs, emerged within $24 \mathrm{hr}$, were obtained from a laboratory colony maintained on 'Bartlett' seedings. The colonies were founded in Mar. 1988

and 1989 from field-collected adults; new

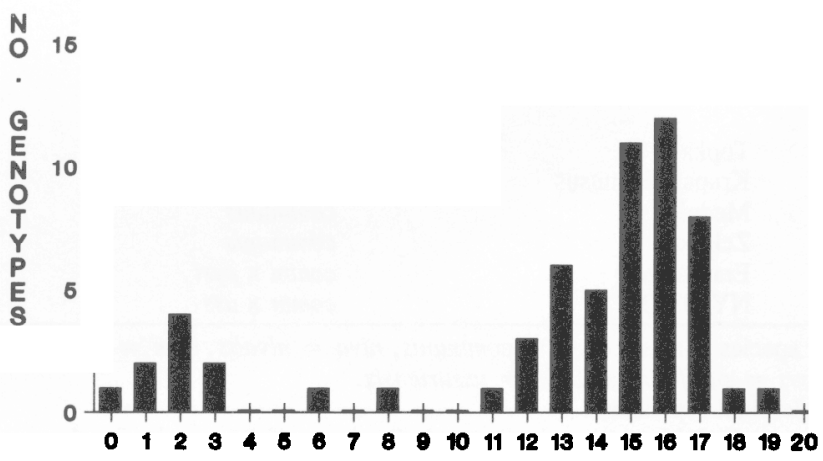

MEAN NO. NYMPHS FEEDING (@UPPER CLASS LIMIT)

Fig. 1. Frequency distribution of mean number of pear psylla [Cacopsylla pyricola (Foerster)] nymphs feeding on eastern European accessions of pear (Pyrus spp.). Bioassay sets 1 and 2 are combined and controls excluded. Individual accessions with means greater than a whole number were combined 
Table 2. Mean number of feeding pear psylla nymphs on 59 plant introductions of pear from Eastern Europe, a susceptible control ('Bartlett') and a resistant control (NY10352).

\begin{tabular}{|c|c|c|c|}
\hline P.I. no. & Name & Species $^{2}$ & Mean $^{y}$ \\
\hline \multicolumn{4}{|l|}{ Set 1} \\
\hline 506373 & $-\cdots$ & & 18.2 \\
\hline 506388 & Poznica & communis & 17.4 \\
\hline 506385 & Para de Zahar de Bihor & communis & 17.0 \\
\hline 483398 & Maslinka & communis & 17.0 \\
\hline 506374 & Petrovka & communis & 16.8 \\
\hline 483396 & Smederevka & communnis & 16.8 \\
\hline 506383 & Tamiioase de Calinesti & communis & 16.6 \\
\hline$\cdots$ & Bartlett & communis & 16.4 \\
\hline 506384 & Coadesele & communis & 16.4 \\
\hline 502173 & & communis & 16.2 \\
\hline 502179 & Sbkta 20/77 & comm $\times$ niva & 16.2 \\
\hline 483368 & Bera Wysmienita & communis & 16.0 \\
\hline 506378 & & communis & 16.0 \\
\hline 506386 & Takisha & communis & 16.0 \\
\hline 502168 & Tikvaca & communis & 15.8 \\
\hline 483376 & Tonkowietka & communis & 15.8 \\
\hline 502167 & Sarajka & communis & 15.8 \\
\hline 483404 & Aromate de Bistrita & communis & 15.6 \\
\hline 506377 & Winiowka Saska & communis & 15.4 \\
\hline 506376 & Saprani II & communis & 15.2 \\
\hline 506372 & Roosevelt & communis & 15.0 \\
\hline 506371 & Panajurka & communis & 14.8 \\
\hline 502169 & Zimska & communis & 14.6 \\
\hline 502170 & Edmundka & communis & 14.4 \\
\hline 502174 & Rosii Untoase & communis & 14.4 \\
\hline 506379 & $\cdots$ & pyraster & 14.2 \\
\hline 506380 & $\cdots$ & pyraster & 14.0 \\
\hline 483397 & Tiranka & communis & 13.8 \\
\hline 502180 & --- & communis & 13.8 \\
\hline 502175 & Urechelnite & communis & 13.6 \\
\hline 506375 & Saprani I & communis & 12.8 \\
\hline 502166 & Saafaranja & communis & 11.8 \\
\hline 483385 & $\cdots$ & communis & 11.8 \\
\hline & NY10352 & comm $\times$ uss & $4.8^{*}$ \\
\hline 502172 & Katman & communis & $3.0^{*}$ \\
\hline 502178 & Smiljerka (?) & communis & $2.4^{*}$ \\
\hline 502165 & Karamanlika & communis & $1.4^{*}$ \\
\hline 502177 & Obican Vodenac & communis & $0.8 ”$ \\
\hline 506382 & & nivalis? & $0.6 "$ \\
\hline 502176 & Smokvarka & comm $\times$ elae? & $0.0 ”$ \\
\hline \multicolumn{4}{|l|}{ Set 2} \\
\hline 483372 & Ilinka & communis & 15.6 \\
\hline 483386 & $\cdots$ & communis & 15.4 \\
\hline 483381 & $\cdots$ & communis & 15.3 \\
\hline \multirow[t]{2}{*}{483390} & Kiselac & communis & 15.0 \\
\hline & Bartlett & communis & 15.0 \\
\hline 483388 & Mustabej & communis & 14.8 \\
\hline 483377 & Verbeln & communis & 14.8 \\
\hline 483378 & Wilenska Plenna & communis & 14.8 \\
\hline 483382 & Ananaska Ceska & communis & 14.2 \\
\hline 483392 & Jesnji Vodenac & communis & 13.2 \\
\hline 483405 & Pitoma Slanopadja & comm $\times$ amyg $^{x}$ & 13.0 \\
\hline 483380 & Prague No. 2 & communis & 13.0 \\
\hline 483371 & Grusza od Nagorskiego & communis & 12.8 \\
\hline 483374 & Krolewna & communis & 12.5 \\
\hline 483400 & Projnjaca & communis & 12.2 \\
\hline 483369 & Bojka & communis & 11.5 \\
\hline 483383 & $\cdots$ & communis & 10.4 \\
\hline 483389 & Topka & communis & $7.6^{*}$ \\
\hline 483387 & Krupan Burnusus & communis & $5.2 *$ \\
\hline 483399 & Mednik & communis & $2.0 "$ \\
\hline 483393 & Zelinka & communis & $2.0^{*}$ \\
\hline 483370 & Erabasma & comm $\times$ pyri & $1.8^{*}$ \\
\hline$\cdots$ & NY10352 & comm $\times$ uss & $1.6^{*}$ \\
\hline
\end{tabular}

${ }^{2}$ Abbreviations for species names: comm $=$ communis, niva $=$ nivalis, elae $=$ elaeagrifolia, amyg $=$ amygdaliformis, pyri $=$ pyrifolia , and uss $=$ ussuriensis.

'Mean of five single-plant replicates.

'The species background of this cultivar is disputed; P. elaeagrifolia maybe involved.

*Significantly different from the susceptible control ('Bartlett') by Dunnett's two-tailed t test at $P=$ 0.05 .

field-collected adults were introduced at 2- not available at the same time, the experimonth intervals. Because all accessions were ments were conducted in two sets. The first set of 39 was assayed from 26 May to 27 June 1988 and the second set of 21 was assayed from 26 June to 13 July 1989.

Trees of the accessions and controls were budded onto 'Bartlett' seedling rootstock and grown in a greenhouse until used in the bioassays. Ten nymphs were transferred to each of the top two fully expanded leaves of actively growing budded trees, $\approx 50 \mathrm{~cm}$ in height. After artifical infestation, the trees were maintained in a laboratory growth room at a constant $25 \pm 1 \mathrm{C}$ and a photoperiod of $16 \mathrm{hr} / 8 \mathrm{hr}$ (L/D). After $24 \mathrm{hr}$, the number of actively feeding nymphs was recorded. Active feeding was determined by the presence of excreted honeydew droplets. Because all genotypes could not be examined at one time, the experimental design was a randomized complete block, in which five independent trials (i.e., blocks) consisted-of single trees of each of the accessions plus single trees of a susceptible control, 'Bartlett', and a moderately resistant control, NY 10352.

Data analysis. The number of nymphs feeding was analyzed as the measure of resistance. For each set, homogeneity of variance was confirmed by Bartlett's test. Normality of residual error was tested by the Shapiro-Wilk statistic W. Data transformation was found to be unnecessary. Analyses of variance were performed to test the significance of trial and genotypic effects. A mixed model was assumed, in which trial effects were random and genotype effects were fixed. Dunnett's two-tailed $t$ test was used to test genotypic means for the significance ( $\alpha=0.05$ ) of differences from the susceptible and resistant controls. Differences between the two sets were tested by a factorial analysis of variance of data for the two control genotypes.

The overall mean of both controls was significantly greater in set 1 than set $2(10.8$ vs. $8.4 ; P=0.002)$. The interaction between sets and control genotypes was not significant $(P=0.19)$. There was no significant difference between sets in mean nymphal feeding on 'Bartlett' $(P=0.15)$, but feeding on NY10352 was significantly less in set 2 than in set $1(P=0.004)$. Therefore, the results are reported separately for each set. In both sets, differences among trials were nonsignificant, while differences among genotypes were significant (Table 1).

Six of the accessions in set 1 were significantly more resistant to nymphal feeding than 'Bartlett', and an additional five resistant accessions were identified in set 2 (Table 2). All 11 plant introductions found to be more resistant than 'Bartlett' were also not significantly different from NY10352, the resistant control. These clones represent nearly $19 \%$ of the accessions released from quarantine thus far. The genotypes were not chosen for virus-indexing and release on the basis of resistance presumed from the original collection records. Thus, we might expect that additional resistant clones will be discovered when additional germplasm from this collection is indexed and released from plant quarantine.

The combined distribution of means for 
both sets is bimodal (Fig. 1). Too many assumptions are required to speculate on the genetic basis of this distribution. However, the original collection records and the release notices indicate that the resistant clones were collected over a wide geographic area (van der Zwet, unpublished data; van der Zwet ,et al., 1987, 1989) and, thus, do not represent a sample from a distinct random mating population. In contrast to the published description of 'Pitoma Slanopadja' (Stancevic et al., 1984), our data indicate that this genotype is susceptible to pear psylla.

An examination of the foliar characteristics of the greenhouse-grown plants suggested that this was a diverse group of germplasm. 'Erabasma' is an interspecific hybrid with $P$. pyrifolia from a research station in Poland. Although it cannot be considered indigenous germplasm, it was included in the analysis because the $P$. communis parent is not known and may have been a genotype of Polish origin. PI 506382 is a clone of $P$. nivalis, with the highly pubescent cordate leaves characteristic of the species. 'Smokvarka' is probably an interspecific hybrid of $P$. communis with $P$. elaeagrifolia, judging from the lanceolate pubescent leaves. Westigard et al. (1970) also found a clone of $P$. nivalis to be resistant, but their clone of $P$. elaeagrifolia was susceptible. The remaining eight resistant clones appear to be P. communis.

Pubescence is not a major factor in feeding deterrence. Although 'Smiljerka', 'Smokvarka', and PI 506382 are pubescent and resistant, three glabrous genotypes were also resistant: 'Krupan Burnusus', 'Karamanlika', and 'Zelinka'. The remaining resistant clones had pubescent young leaves that became glabrous upon expansion and aging. In addition, PI 502179, presumably $P$. nivalis or an interspecific hybrid with $P$. communis, was quite susceptible but pubescent.

Additional data are needed on fruit characteristics to better assess the usefulness of this germplasm for breeding, but a preliminary evaluation of 35 of the pure $P$. communis genotypes indicates that 'Mednik', 'Topka', and 'Zelinka' have fruit of at least $5 \mathrm{~cm}$ in diameter. "Hybridization of these cultivars with genotypes of large fruit size should allow selection of seedlings with acceptable fruit size.

We have identified eight $P$. communis clones with resistance to pear psylla nymphal feeding. Although studies of oviposition and longer-term observations of development and mortality are needed to more completely characterize the resistance in these genotypes, our previous experience with " $P$. ussuriensis-derived sources of resistance, which also elicit nymphal feeding inhibition, leads us to conclude that the level and type of resistance in this germplasm will be valuable. The eastern European germplasm is a new source, of resistance from a gene pool not previously extensively evaluated or available to breeders in Western Europe and North America. Incorporation into breeding programs will broaden the genetic base of host plant resistance to the pear psylla.

\section{Literature Cited}

Butt, B. A., L.C. Stuart, and R.L. Bell. 1988. Feeding behavior of pear psylla (Homoptera: Psyllidae) nymphs on susceptible and resistant Pyrus germplasm. J. Econ. Entomol. 81:13941397.

Butt, B. A., L.C. Stuart, and R.L. Bell. 1989. Feeding, longevity, and development of pear psylla (Homoptera: Psyllidae) nymphs on resistant and susceptible pear genotypes. J. Econ. Entomol. 82:458-461.

Briolini, G., A. Cappeli, L. Rivalta, and P. Ro- sati. 1988. Observations on Pyrus communis resistance to Psylla pyri. Acta Hort. 224:211221.

Croft, B. A., E.C. Burts, H.E. van de Baan, P.H. Westigard, and H. Riedl. 1989. Local and regional resistance to fenvalerate in Psylla pyricola Foerster (Homoptera: Psyllidae) in western North America. Can. Entomol. 121:121-129.

Harris, M. K. 1973. Host resistance to the pear psylla in a Pyrus communis $\times P$. ussuriensis hybrid. Environ. Entomol. 2:883-887.

Harris, M.K. and R.C. Lamb. 1973. Resistance to the pear psylla in pears with Pyrus ussuriensis lineage. J. Amer. Soc. Hort. Sci. 98:378381.

Quamme, H.A. 1984. Observations of psylla resistance among several pear cultivars and species. Fruit Var. J. 38:34-36.

Quarta, R. and D. Puggioni. 1985. Survey on the variety susceptibility to pear psylla. Acta Hort. 159:77-86

Stancevic, A., J. Gavirilovic,;. Stankovic, and T. van der Zwet. 1984. 'Pitoma Slanopadja', a natural pear hybrid between Pyrus amygdaliformis and P. communis. HortScience 19:254255.

Stankovic, D.M. and P.D. Misic. 1978. Yugoslavia-An important source of fruit germplasm. Chron. Hort. 18:3-4.

van der Zwet, T., V. Cociu, B. Czarnecki, J. Nyeki, and J. Blazek. 1989. Collecting Pyrus germplasm in Romania, Poland, Hungary, and Czechoslovakia. HortScience 24:420-424.

van der Zwet, T., D. Stankovic, and B. Ristevski. 1987. Collecting Pyrus germplasm in Yugoslavia. HortScience 22:15-21.

Vavilov, N.I. 1951. The origin, variation, immunity, and breeding of cultivated plants. Ronald Press, New York.

Westigard, P. H., M.N. Westood, and P.B. Lombard. 1970. Host preference and resistance of Pyrus species to the pear psylla, Psylla pyricola Foerster. J. Amer. Soc. Hort. Sci. 95:34-36.

Westigard, P.H. and R.W. Zwick. 1979. Pear psylla control: Current status and future potentials. Ann. Rpt. Oregon Hort. Soc. 70:90-94. 